\title{
The Perceptions of Entrepreneurs on the Registration of Sales in Czech Republic
}

\author{
Frantisek Sejkora ${ }^{1, *}$, Martina Mlazovsky ${ }^{1}$, \\ ${ }^{1}$ University of Pardubice, Faculty of Economics and Administration, Institute of Business Economics \\ and Management, Studentska 95, 53210 Pardubice, Czech Republic.
}

\begin{abstract}
.
Research background: Compliance with tax laws can be considered a global problem facing all tax administrations to a greater or lesser extent. Individuals take various steps to minimize tax liability, which is rational economic behavior. If the tax liability is minimized as part of an individual's infringement, it is tax evasion. Many countries have begun to implement various tools using advanced technologies to address these leaks. Especially in European countries, there has recently been a trend in preventing sales cuts by introducing a sales registration system.

Purpose of the article: Electronic registration of sales is a relatively new project in the Czech Republic. The main reasons for the introduction of electronic sales records were better tax collection and also the leveling of the market environment by reducing the share of the gray economy. The aim of the article is to analyze the perception of entrepreneurs to this new tool on the basis of a questionnaire survey. The research was carried out in the area of "Accommodation, food and beverage service activities". This sector is considered to be one of the most problematic due to the presence of the shadow economy and is also one of the most important sectors in terms of the number of business entities.
\end{abstract}

Methods: The data were analyzed by the chi-square test of independence and descriptive statistics.

Findings \& Value added: The results show a negative attitude of entrepreneurs to this new tool.

Keywords: Tax Evasion; Electronic Registration of Sales; Small and Medium Enterprises

JEL Classification: $D 22 ; H 25 ; K 34$

\footnotetext{
* Corresponding author: frantisek.sejkora@upce.cz
} 


\section{Introduction}

Tax revenues play a crucial role in government expenditure financing from which the citizens may benefit through various public services. This requires citizens to pay taxes and the government to manage taxes effectively - requirements posing a significant challenge in many countries of the world. The importance of tax revenues for states became apparent especially in 2015 with the adoption of a commitment to ensure sustainable development goals financing [1]. The most favoured instrument to increase tax revenues is excise duties, especially the value added tax, which is less harmful than direct taxes [2].

Although it is frequently said that the only certainty in your life is death and taxes, taxes are by far not so unavoidable and individuals take various steps to reduce their tax liabilities. Tax liability reduction is possible both in the legal and the illegal levels. In the first case, the individual uses the possibilities of tax reduction within the frame of all the alternative procedures stipulated by the tax law. The second case is tax evasion, which is the individual's illegal action aimed at unauthorized tax liability reduction [3]. Tax evasion has various forms, such as income reduction, cost overvaluation, failure to submit a tax return, unofficial wages. The question of the individual's (company's) motivation to evade taxes is dealt with in [4]. Tax evasion is part of so-called underground economy. Authors [5] engaged in labour market analysis find that employees working in underground economy suffer under worse working conditions. Tax evasion is a big problem in the light of public budgets. The presence of this phenomenon requires that the government spend funds on supervision of and punishing such practices.

In order to reduce tax evasion, many countries have recently started to implement various instruments using advanced information and communication technologies. This procedure is generally called "fiscalization" (Electronic Fiscal Device), which is a group of measures adopted by the taxpayer to help the tax office monitor business transactions [6]. One of the first countries to adopt fiscalization was Greece in 1988. In the course of the coming years, registration by means of electronic fiscal devices spread to other countries, such as Brazil and Argentina, and subsequently, after the turn of the $21^{\text {st }}$ century, it spread also to some countries in Eastern Africa. In the course of the coming years, keeping records by means of fiscalization spread to other European countries, including neighbouring Slovakia or Croatia [6].

Because of the frequent implementation of fiscal devices in the world, the topic has become subject of empirical studies. Empirical studies proving the influence of fiscal devices on compliance with tax regulations, which are chiefly based on macroeconomic data, are not unambiguous. In most cases, other measures have been implemented together with EFDs and although most of the said countries measure the level of compliance with tax liabilities, they frequently do not attempt to isolate the influence of the individual measures; thus, the possible positive effect may not be evaluated as a result of EFD implementation. Authors [6] came to several conclusions by means of a questionnaire survey made in the countries where EFDs had been implemented. EFDs are not the only true method to guarantee a tax revenue increase and compliance with tax liabilities; they are efficient only as part of a complex policy aimed at tax liability evasion combating. The authors did not find a connection between EFD implementation and an increase in VAT collection as a percentage of GDP. In Romania, authors Bostan et al. [7] tested the influence of EFDs on VAT collection and tax efficiency; the results show an improvement in VAT collection but also a decrease in VAT collection efficiency. Implementation of EFDs had a positive impact on revenues from VAT in Tasmania; however, the impact was smaller than expected [8]. An increase in the taxpayers' awareness is a key factor for the adoption and use of EFDs by the taxpayers [9]. The benefits of EFD implementation based on microeconomic data are more favourable. Authors [10] specify that the adoption of 
electronic invoicing in the manufacturing industry has contributed to a tax revenue increase. In Hungary, they analysed the influence in the retail sector and in accommodation and catering services. The reported turnover increased by $23 \%$ in small businesses and by 35.1 $\%$ in retailing. As regards big companies, an impact was observed only in big catering businesses [11]. Authors [12] report positive benefits of EFD innovations implementation on compliance with tax regulations. The use of information for tax administration is beneficial especially in African states which are characterized by low tax revenues [13]. In Rwanda, authors [14] compared VAT collection from companies which had already implemented cash registers and from companies which had not been engaged in the system yet, using the econometric technique of difference in differences; they calculated an impact on VAT collection of approximately $6.5 \%$.

Literature specifies that compliance with tax regulations grows with the probability of an audit and strictness of punishment. In this connection, some countries have implemented other instruments simultaneously with EFDs: system supervision by third parties. In Brazil, for instance, the adoption of pecuniary rewards for consumers led to a significant increase in companies' sales [15]. Authors [8] have dealt with the question of interaction between the knowledge of regulations and the request for a bill and compliance with tax regulations by the businessmen. Portugal has introduced the possibility of refunding part of VAT to the consumer if he/she requires an invoice from the seller [16].

The topic of electronic fiscal devices as an instrument used against tax evasion has become very up-to-date and discussed also in the Czech Republic. In this connection, Act No. 112/2016, on sales registration, has introduced a new registration obligation for businessmen in the Czech law: the so-called electronic registration of sales (EET). In order to implement the system easier, a total of four stages of gradual introduction of the obligation to register sales have been planned, depending on the businessmen's objects. There are several reasons for introduction of EET in the Czech Republic. First and foremost, it is an instrument to prevent tax evasion and to reduce underground economy. According to the legislator, it should, together with the other implemented instruments, such as the control statement, ensure more effective tax collection; and in consequence of the restriction in underground economy, the state budget income should also increase. The next possible benefit is equalization of the businessmen's competitive conditions, which have so far been considerably deformed owing to tax evasion by some businessmen. Besides this, the Ministry of Finance expects a reduction in administrative demands for honest businessmen because the system will enable targeting tax audits at problematic entities and minimizing audits of honest businessmen. EET should also reduce illegal payment of parts of wages, which consisted in the employees getting part of their wages officially and part of their wages in cash, the latter being frequently financed from nondisclosed sales. The principle of electronic registration of sales in the Czech Republic is not totally identical to any of the systems working in foreign countries; however, it is most similar to the Croatian system. The Czech system uses the principle of online connection to the financial administration's storage site. The main aspects which led to the election of online registration were the low total cost ratio for the businessmen and the state administration and the real time data transfer to the tax administrator, which minimizes the entity's possibility to illegally change information on sales [17]. Compliance with the law by the state is supervised by the financial and customs administration. Together with the adoption of electronic registration, the value added tax for catering and accommodation services was reduced from the basic rate of $21 \%$ to the first reduced rate of $15 \%$ and subsequently to the second reduced rate of $10 \%$. Registration of sales was also supervised by the public until the outbreak of the Covid crisis: participants could win valuable prizes in a bill lottery. 


\section{Scientific Methods Used}

The aim of the article is to analyse, by means of a questionnaire survey, the attitude of respondents to EET pursuing business in the CZ-NACE field of business of Accommodation, Catering and Innkeeping Activities in the Pardubice Region. This sector is considered to be one of the most problematic ones owing to the presence of underground economy; it is also one of the most important sectors by the number of entities pursuing business. As regards the number of respondents addressed, the authors were led by the endeavour to ensure sample representativeness. The questionnaire was processed on the Survio online questionnaire platform. The data were collected through the Internet by means email addresses obtained from the MagnusWeb database. The critics of EET introduction had specified that especially smaller establishments with lower sales and establishments located in smaller municipalities would be forced to restrict or terminate their business owing to the high costs of EET introduction and operation. Due to this reason, two questions in the questionnaire served to classify the respondents according to the number of inhabitants in the municipality where they pursued their business and the amount of their annual turnover. The remaining seven questions dealt with the evaluation of the researched problem.

A total of 195 respondents were addressed for the purposes of the research. 26 of them replied that they were not able to complete the questionnaire. The most frequent reason was termination of business. 56 emails of the total number returned owing to an invalid email address. The questionnaire was completed by a total of 113 respondents.

The following hypotheses were examined in connection with the fears of EET impact on establishments with lower sales and establishments in smaller municipalities:

$\mathrm{H}_{0} / \mathrm{H}_{1}$ There is not (there is) a relation between the opinion on the introduction of EET and the municipality size.

$\mathrm{H}_{0} / \mathrm{H}_{2}$ There is not (there is) a relation between the opinion on the introduction of EET and the amount of sales.

$\mathrm{H}_{0} / \mathrm{H}_{3}$ There is not (there is) a relation between the economic impact of EET introduction and the municipality size.

$\mathrm{H}_{0} / \mathrm{H}_{4}$ There is not (there is) a relation between the economic impact of EET introduction and the amount of sales.

Furthermore, the advantages and disadvantages of EET introduction were examined from the respondents' point of view. The businessmen could check multiple answers for the questions.

The hypotheses were tested by means of a chi-squared independence test in contingency tables. The test is based on the idea of comparing observed and expected frequencies. We decided to adopt or reject the given hypotheses on the basis of the chi-squared test statistics. If the test statistics got over the critical value for the selected significance level of $\alpha=0.05$, we rejected the null hypothesis and confirmed the alternative one and vice versa.

\section{Results and Discussion}

The first mentions of EET preparation raised a wave of disagreement in the population. Negative responses were heard especially from businessmen affected by the change most significantly. The objective of the first question was to get the respondents' opinion on the introduction of electronic registration of sales. A total of $42(37.2 \%)$ respondents specified that they agreed with EET introduction and a total of $71(62.8 \%)$ respondents specified that 
they disagreed with EET introduction. On the basis of these attitudes, we tested whether the attitudes differed in relation to the size of the municipality where the businessmen pursued their business and in relation to the amount of sales. Table No. 1 and Table No. 2 display the real and the expected frequencies of responses to verify the first and the second hypotheses.

Table 1. Real and expected frequencies of responses to verify the first hypothesis

\begin{tabular}{|l|c|c|c|c|}
\hline $\begin{array}{l}\text { Attitude/Number of } \\
\text { inhabitants }\end{array}$ & $\begin{array}{c}100-1,000 \\
\text { inhabitants }\end{array}$ & $\begin{array}{c}1,001-10,000 \\
\text { inhabitants }\end{array}$ & $\begin{array}{c}10,001-50,000 \\
\text { inhabitants }\end{array}$ & $\begin{array}{c}\text { More than 50,000 } \\
\text { inhabitants }\end{array}$ \\
\hline $\begin{array}{l}\text { I agree with EET } \\
\text { introduction }\end{array}$ & $18(16,72)$ & $13(11,15)$ & $3(5,57)$ & $8(8,54)$ \\
\hline $\begin{array}{l}\text { I disagree with EET } \\
\text { introduction }\end{array}$ & $27(28,27)$ & $17(18,84)$ & $12(9,42)$ & $15(14,45)$ \\
\hline
\end{tabular}

Source: own processing

Table 2. Real and expected frequencies of responses to verify the second hypothesis

\begin{tabular}{|l|c|c|c|}
\hline $\begin{array}{l}\text { Attitude/Annual } \\
\text { turnover }\end{array}$ & $\begin{array}{c}\text { CZK } \\
100,001-499,999\end{array}$ & $\begin{array}{c}\text { CZK } \\
500,000-999,999\end{array}$ & $\begin{array}{c}\text { CZK } \\
1,000,000 \text { and more }\end{array}$ \\
\hline $\begin{array}{l}\text { I agree with EET } \\
\text { introduction }\end{array}$ & $14(11,15)$ & $22 / 24,16)$ & $6(6,69)$ \\
\hline $\begin{array}{l}\text { I disagree with EET } \\
\text { introduction }\end{array}$ & $16(18,84)$ & $43(40,84)$ & $12(11,31)$ \\
\hline
\end{tabular}

Source: own processing

The tables display the real and expected (in the brackets) frequencies of answers concerning the attitude to EET introduction in relation to the size of the municipality where the respondents performed their business activities and in relation to their annual turnover. In the case of the first hypothesis, the calculated value of the chi-squared test criterion is 2.59; the theoretical chi-squared value for the significance level of $\alpha=0.05$ with 3 degrees of freedom is 7.8. The calculated value of the tested criterion is lower than the theoretical value of 7.8; therefore, we will not reject the null hypothesis. Thus, the conclusion is that most respondents do not agree with EET introduction and there is no statistically significant difference in the respondents' attitudes to introduction of electronic registration of sales in relation to the size of the municipality where they perform their activities.

In the case of the second hypothesis, the calculated value of the chi-squared test is 1.58 ; the theoretical chi-squared test value for the significance level of 0.05 with 2 degrees of freedom is 6.0. The calculated value of the test criterion is lower than the theoretical value; therefore, we will not reject the null hypothesis. Thus, the conclusion is that most respondents do not agree with EET introduction and there is no statistically significant difference in the respondents' attitudes in relation to the amount of their turnover. Research results [18] have also confirmed the respondents' negative attitude to EFD introduction in Tanzania. The last, seventh, question was aimed at the future use of EET in the Czech Republic. A bulk of the respondents, $68 \%$, do not anticipate any future for this instrument.

The second question was aimed at the economic impact on the businessmen. More than one half of the respondents $(62.8 \%)$ specified that the introduction of sales registration had had no or small economic impact on their businesses. $37.17 \%$ respondents had experienced a big economic impact. A relatively small economic impact is attributable to the online EET system introduced in the Czech Republic. In addition, EET introduction had brought a decrease in the basic VAT rate of $21 \%$ to $10 \%$ for catering services and later also for accommodation services; and last but not least, businessmen are able to claim tax allowances for technology purchase. The economic impact is quantifiable by means of oneoff expenditures in the field of technology purchase and by means of repeated expenditures 
connected with EET operation. The third question examined the specific devices purchased by the respondents in relation to EET introduction; the fourth question quantified the costs of such devices. Most of the respondents specified that they had to purchase software and a cash register. By contrast, $5.4 \%$ of the respondents did not have to purchase any technologies and $25 \%$ of the respondents did not have to purchase an Internet connection. As regards the quantification of the purchase expenditures, $26.8 \%$ of the respondents specified that the expenditures had amounted to up to CZK 5,000, 40.2\% of the respondents specified that the expenditures had amounted to up to CZK 20,000 and $33 \%$ of the respondents specified that the expenditures had amounted to over CZK 20,000. Tables No. 3 and No. 4 specify the frequency of answers in relation to the economic impact, classified according to the size of the municipality where the respondents pursue their business and their annual turnover. These tables are simultaneously used to evaluate the third and the fourth hypotheses.

Table 3. Real and expected frequencies of responses to verify the third hypothesis

\begin{tabular}{|l|l|l|l|l|}
\hline $\begin{array}{l}\text { Economic } \\
\text { impact/municipality } \\
\text { size }\end{array}$ & $\begin{array}{l}100-1,000 \\
\text { inhabitants }\end{array}$ & $\begin{array}{l}1,001-10,000 \\
\text { inhabitants }\end{array}$ & $\begin{array}{l}10,001-50,000 \\
\text { inhabitants }\end{array}$ & $\begin{array}{l}\text { More than } \\
50,000 \\
\text { inhabitants }\end{array}$ \\
\hline None & $11(12,34)$ & $8(8,23)$ & $5(4,11)$ & $7(6,30)$ \\
\hline Small & $18(15,93)$ & $9(10,62)$ & $6(5,31)$ & $7(8,14)$ \\
\hline Big & $16(16,72)$ & $13(11,15)$ & $4(5,57)$ & $9(8,54)$ \\
\hline
\end{tabular}

Source: own processing

Table 4. Real and expected frequencies of responses to verify the third hypothesis

\begin{tabular}{|l|l|l|l|}
\hline $\begin{array}{l}\text { Economic } \\
\text { impact/annual turnover }\end{array}$ & $\begin{array}{l}\text { CZK 100,001- } \\
499,999\end{array}$ & CZK 500,000-999,999 & $\begin{array}{l}\text { CZK 1,000,000 and } \\
\text { more }\end{array}$ \\
\hline None & $10(8,23)$ & $4(4,93)$ & $17(17,83)$ \\
\hline Small & $12(10,62)$ & $5(6,37)$ & $23(23,01)$ \\
\hline Big & $8(11,15)$ & $9(6,69)$ & $25(24,16)$ \\
\hline
\end{tabular}

Source: own processing

In the case of the third hypothesis, the calculated value of the chi-squared test criterion was 1.99; the theoretical chi-squared value for the significance level of $\alpha=0.05$ with 6 degrees of freedom was 12.6. In the case of the fourth hypothesis, the chi-squared test value was 2.78 and the theoretical chi-squared test value for the significance level of $\alpha=0.05$ with 4 degrees of freedom was 9.5 . In both the cases, the calculated value of the tested criterion was lower than the theoretical value; therefore, we did not reject the null hypothesis. Thus, the conclusion is that there is no statistically significant difference in the economic impact of the introduction of electronic registration of sales in relation to the turnover and the size of the municipality where the businessmen pursue their business.

Questions number five and six examined the respondents' view of the advantages and disadvantages resulting from EET introduction. The respondents could check multiple answers to these questions. The following table No. 5 summarizes the respondents' answers concerning the advantages resulting from EET introduction. 
Table 5. Advantages resulting from EET introduction.

\begin{tabular}{|l|c|c|}
\hline Response options & Frequency of response & Relative frequency \\
\hline Equalization of business conditions & 24 & $21.40 \%$ \\
\hline Underground economy repression & 17 & $15.20 \%$ \\
\hline Better supervision of employees & 16 & $14.30 \%$ \\
\hline Better business overview & 11 & $9.80 \%$ \\
\hline No advantages & 63 & $55.8 \%$ \\
\hline
\end{tabular}

Source: own processing

Most respondents specified that the introduction of sales registration had brought them no advantages. These respondents were chiefly entities based in smaller municipalities. One of the most frequently mentioned advantages was equalization of business conditions and underground economy repression. These conclusions correspond to studies $[18,19]$ in which the respondents specified that the greatest advantage was underground economy repression. The less frequent advantages were a better business overview and a better supervision of employees. We can deduct from this that the respondents had had a good overview of their business activities even before the introduction of electronic registration of sales. In contrast, businessmen in Tanzania recommended using EFDs owing to better supervision of employees and better business records [18].

The survey did not omit the disadvantages associated with the introduction of sales registration. The following table displays such disadvantages.

Table No. 6 Disadvantages resulting from EET introduction

\begin{tabular}{|l|c|c|}
\hline Response options & Frequency of response & Relative frequency \\
\hline Increase in the businessmen's expenses & 73 & $64.60 \%$ \\
\hline Greater supervision of business by the state & 22 & $19.40 \%$ \\
\hline Increase in administration & 51 & $45.10 \%$ \\
\hline Unexpected system failures & 22 & $19.46 \%$ \\
\hline Greater time consumption in customer service & 57 & $50.44 \%$ \\
\hline I do not see any disadvantages & 23 & $20.35 \%$ \\
\hline
\end{tabular}

Source: own processing

The same way as in the case of advantages, the respondents could choose multiple answers from several options. Each respondent marked at least one disadvantage. The most frequent response was an increase in expenses and in administration and greater time consumption in customer service. The next group of respondents were afraid of a danger of abuse or leakage of information relating to the businessmen. The disadvantages naturally also included increased expenses and greater tax liabilities. In Croatia, the disadvantages included an increase in expenses followed by frustration and time to serve customers.

\section{Conclusion}

Currently, the third and the fourth waves of electronic registration introduction have been suspended owing to the pandemics in the Czech Republic until the end of 2020. The respondents who have already introduced electronic registration do not agree with the introduction and do not see any future for this instrument. Respondents in Tanzania also have a negative attitude to the introduction of EFDs; the reason given by them is chiefly high costs of device purchase [18]. The fears of the objectors that the introduction of this instrument would chiefly harm smaller businessmen have not been fulfilled. On the contrary, the statistics specifies that there has rather been an increase in the number of businessmen in this segment and not only in the examined region [20]. The given economic impact on the respondents, classified by the amount of their turnover and the size of the 
municipality where they pursue their business, also does not show any statistically significant difference in their responses. We may deduct from this conclusion that the introduction of the system has not resulted in any discrimination or a disadvantage to certain groups. In spite of their disagreement with EET introduction, the respondents see the greatest advantage of this instrument in underground economy repression. This opinion is supported also by respondents included in the studies [18,19]. This may be interpreted in such a way that the respondents are aware of the tax evasion problem, which is part of underground economy, and that the introduction of similar instruments in the world is justified. In contrast, they see the disadvantages mainly in the further administrative burden. This may originate from the recent introduction of new instruments against tax evasion, especially in the field of VAT. It would be beneficial if the legislature reacted to the certain existing duplicity and reduced the businessmen's recording liabilities. One of the possibilities is to exempt businessmen liable to register sales if they are willing to move to the variant of lump-sum tax payment. Last but not least, a constantly discussed problem in the Czech Republic is tax administration digitalization and a single collection point.

Acknowledgements: This article was supported by the scientific research project of the Czech Sciences Foundation Grant No: 19-15498S. This paper was supported by the Student Grant Competition (grant no. 16) of University of Pardubice in 2020.

\section{References}

1. Mawejje, J., \& Sebudde, R. K. (2019). Tax revenue potential and effort: Worldwide estimates using a new dataset. Economic Analysis and Policy, 63, 119-129.

2. Cnossen, S. (2015). Mobilizing VAT revenues in African countries. International Tax and Public Finance, 22(6), 1077-1108.

3. Alm, J., Liu, Y., \& Zhang, K. (2019). Financial constraints and firm tax evasion. International Tax and Public Finance, 26(1), 71-102.

4. Alm, J. (2019). What motivates tax compliance? Journal of Economic Surveys, 33(2), 353-388.

5. Williams, C. C., \& Horodnic, I. A. (2019). Evaluating working conditions in the informal economy: evidence from the 2015 European Working Conditions Survey. International Sociology, 34(3), 281-306.

6. Casey, P., \& Castro, P. (2015). Electronic Fiscal Devices (EFDs) An Empirical Study of their Impact on Taxpayer Compliance and Administrative Efficiency. International Monetary Fund, 15-73.

7. Bostan, I., Popescu, C., Istrate, C., Robu, I. B., \& Hurjui, I. (2017). The impact of taxation of the domestic economic transactions on the VAT collection through electronic fiscal devices. Amfiteatru Economic, 19(45), 581.

8. Fjeldstad, O. H., Kagoma, C., Mdee, E., Sjursen, I. H., \& Somville, V. (2020). The customer is king: Evidence on VAT compliance in Tanzania. World Development, 128, 104841.

9. Mandari, H., Koloseni, D., \& Nguridada, J. (2017). Electronic fiscal device (EFD) acceptance for tax compliance among trading business community in Tanzania: the role of awareness and trust. International Journal of Economics, Commerce and Management, 5(3), 142-158. 
10. Fan, H., Liu, Y., Qian, N., \& Wen, J. (2018). The Dynamic Effects of Computerized VAT Invoices on Chinese Manufacturing Firms. National Bureau of Economic Research, 24414.

11. Lovics, G., SZÖKE, K., Tóth, C. G., \& Ván, B. (2019). The Effect of the Introduction of Online Cash Registers on Reported Turnover in Hungary (No. 2019/137). Magyar Nemzeti Bank (Central Bank of Hungary).

12. Nanthuru, S. B., Pingfeng, L., \& Guihua, N. (2017). An Evaluation of Electronic Fiscal Device Effectiveness on Tax Compliance-A Risk Management Innovation: Case Study of Malawi. INNOVATION AND MANAGEMENT, 714-721.

13. Mascagni, G. (2018). From the lab to the field: A review of tax experiments. Journal of Economic Surveys, 32(2), 273-301.

14. Eissa, N. and Zeitlin, A. (2014) Using mobile technologies to increase VAT compliance in Rwanda. Mimeo, McCourt School of Public Policy, Georgetown University.

15. Naritomi, J. (2019). Consumers as tax auditors. American Economic Review, 109(9), 3031-72.

16. Wilks, D. C., Cruz, J., \& Sousa, P. (2019). "Please give me an invoice": VAT evasion and the Portuguese tax lottery. International Journal of Sociology and Social Policy, 39(5/6), 412-426.

17. Marethova, Z., \& Snopkova, P. (2018). Electronic Registration of Sales in the Czech Republic-theory and praxis. In Optimization of Organization and Legal Solutions concerning Public Revenues and Expenditures in Public Interest (Conference Proceedings), ed. Ewa Lotko, Urszula K. Zawadzka-Pak, Michal Radvan (pp. 651664). Temida 2.

18. Kaisi, C. G. (2019). Assessing the adoption of electronic fiscal devices (efds) in increasing revenue collection: A case of kinondoni municipality, Tanzania (Doctoral dissertation, Mzumbe university).

19. Tot, A., \& Detelj, K. (2014). Implementation of Cash Transaction Fiscalization Procedure in Businesses: Case of Croatia. In Central European Conference on Information and Intelligent Systems. Faculty of Organization and Informatics Varazdin, 48-55.

20. Ministry of industry and trade (2020, September 3). Indices. Retrieved from: https://www.mpo.cz/en/business/licensed-trades/statistical-data-on-entrepreneurs/numb er-of-trade-licenses-according-to-professions-in-individual-regions---226393/. 